\title{
Delta formations associated with high-frequency (annual?) lake-level fluctuations: An example from the uppermost Pleistocene Gokarna Formation, Kathmandu Valley, Nepal
}

\author{
T Sakai†*, AP Gajurelł, H Tabata§ and BN Upretił \\ † Department of Geoscience, Shimane University, Matsue, Shimane 690-8504, JAPAN \\ ‡ Department of Geology, Tri-Chandra Collage, Tribhuvan University, Ghantaghar, Kathmandu, NEPAL \\ § Gifu Academy of Forest Science and Culture, Mino, Gifu 501-3714, JAPAN \\ * To whom correspondence should be addressed. E-mail: sake@riko.shimane-u.ac.jp
}

The Kathmandu Valley, one of the intermontane basins in the lesser Himalayan Belt, is filled with fluvio-lacustrine deposits dating from the Pliocene. After $5 \mathrm{ka} \mathrm{BP}$, sediments in the central part of the basin occur as depositional terraces (Patan, Thimi and Gokarna terraces), the formation of which has been interpreted as being related to lake-level changes (Yoshida et al. 1984). The uppermost Pleistocene Gokarna Formation, which forms the GokarnaTerrace, has been interpreted asformingin conjunction with long-term lake-level rises associated with basin pluggingand lake-level fallscaused by lakewater out-bursts at the basin outlet (Sakai et al . 2000). This formation is composed of small stacked Gilbert-Type delta successions, thethickness of each is up to 10 $\mathrm{m}$. Small-scale, high-frequencylake-level fluctuation is especially recorded in the delta front deposits of the lower part of the formation that accumulated between ca. 50-35ka. Based on the large number of fluctuations seen even in small outcrops, Sakai et al. (2001) inferred that thesehigh frequency cycles wereformed by annual lake-level changes. Our recent work has detected at least 21 cyclesin a 40-m wideoutcrop. Previous work was limited to the delta front, and broad scale stratigraphic architecture associated with the short-term fluctuations was thus unclear. Here we describe lateral facies changes of delta deposits formed in association with short-term lake-level changes and discuss their processes of formation.

Two types of delta deposits, juxtaposed in the same stratigraphic horizon, were identified in the lower part of the Gokarna Formation. Delta front deposits of the first type(type1) are represented by $0.5-3 \mathrm{~m}$ thick, tabular cross-stratified sand and silt beds. The silt beds are continuous with prodelta deposits. Most of thesilt beds pinch out near thetop of the deltafront, but someextend beyond the deltafront and cover the deltaplain sand beds deposited prior to the silt beds. Delta plain deposits of this typearecharacterized bylenticular, epsilon cross-stratified fluvial channel fill sand and silt beds and flood plain silt beds. Silt beds in the channel fill deposits continue into the surrounding flood plain silt beds in many cases. Delta front deposits of the second type (type 2) arecharacterized by thick, steeply dipping (ca. 30) foreset sand beds. Thicknesses commonly reach 5-10 m. Small sand wedges (up to $1 \mathrm{~m}$ thick and 2-3 $\mathrm{m}$ wide) are frequently attached to the lower part of the foreset slope, and small gullies are developed in the upper part. The wedges contain tabular cross-stratification, are flat-topped, and are covered by thin trough cross-stratified fluvial channel fill deposits which are, in turn, overlain by delta front deposits prograded after sand wedge formation. In some delta front sand beds, inclined foreset beds tend to beflat to the up-dip direction and gradeinto trough crossstratified sand beds with sheet-like geometry (up to $1 \mathrm{~m}$ thick), which are of braided stream origin.
The interbedded silt beds in thetype 1 delta front deposits that continuefrom the prodelta and extend onto the delta plain deposits and those in the fluvial channel fill deposits spreading into the surrounding flood plain deposits suggest that they accumulated when the delta plain was inundated and delta progradation occurred during lake-level lowstand. Theattached small delta wedges in the type 2 delta front topped by fluvial channelsrepresenttemporary deltasformed when lakelevel fell. This also indicates that type 2 delta progradation occurred mainly duringlake-level highstand. Transition from delta front to braided stream deposits on the delta plain indicates some of the type 2 deltadepositsaccumulated duringlake-level rise, when sediment accumulation on the deltaplain wassynchronized with lake-level rise. The differencesin level of thetops of the delta front deposits and those of the attached sand wedges show that the amplitude of lake-level fluctuations was $6 \mathrm{~m}$ at most (average ca. $3 \mathrm{~m}$ ). Changes in fluvial style from meandering (type 1) to braided streams (type 2) can beexplained byalternating, possiblyannual, wet and dry periods. In the lowstand phase (dry period), meanderingstreams0could develop dueto lower water discharge. During lake-level rise (i.e. wet period), larger water discharge together with enhanced sediment supply could then produce braided streams.

Thehigh-frequency lake-level fluctuation described above does not occur in the upper part of the Gokarna Formation. One possible explanation for the absence of cyclicity in this part of the succession is that the lake could then have been more extensive: if lakes are wider, larger volumes of water are required to produce fluctuations in level. Climate change is another possibility. Our age measurements show that the upper part of the Gokarna Formation was deposited at about 17 ka BP, indicating that accumulation occurred around the last glacial maximum. Both climate change and more extensive lake area may thus contribute to the absence of sediment cycles in the upper part of the Gokarna Formation.

\section{References}

Sakai T, AP Gajurel, H Tabata and BN Upreti. 2001. Small amplitude lake level fluctuations recorded in aggrading deltaic deposits of the lower parts of the Upper Pleistocene Thimi and Gokarna formations, Kathmandu Valley, Nepal. J Nepal Geol Soc 25: 43-51

Sakai T, T Takagawa, AP Gajurel and H Tabata. 2000. Reconstruction of depositional environment and paleoclimate change from the Quaternary basin fill succession of the Kathmandu Valley, Nepal. Int Workshop Himalayan Uplift Climate Change. Program and Abstract, 27-31

Yoshida M and Igarashi Y. 1984. Neogene to Quaternary lacustrine sediments in the Kathmandu Valley, Nepal. J Nepal Geol Soc 4:73100 